\title{
DigITAL COMPETENCES FOR TEACHERS - THE DIGI.KOMPP MODEL IN AN INTERNATIONAL COMPARISON AND IN THE PRACTICE OF AUSTRIAN TEACHER TRAINING
}

\author{
Gerhard Brandhofer ${ }^{1}$ and Marlene Miglbauer ${ }^{2}$ \\ ${ }^{1}$ University College of Teacher Education Lower Austria, Mühlgasse 67, \\ 2500 Baden, Austria. \\ ${ }^{2}$ University College of Virtual Teacher Education, Thomas Alva Edison \\ Straße 1, 7000 Eisenstadt, Austria
}

\begin{abstract}
The digital competences of teachers have not yet been given sufficient attention in Austria. In order to meet this need, the digi.kompP model has been developed on behalf of the Federal Ministry of Education and Women's Affairs, led by the University College of Virtual Teacher Education. Based on national and international framework models, the competency model is to serve as an instrument for self-assessment and continuous professional development as well as for (higher) school development. The following is a brief overview of international models that were relevant for the development of the competence grid. After that the competence grid itself and its categories are presented. The article concludes with a discussion of the integration of the competence grid into the international framework and its benefits in the Austrian education system. This article aims to make a theoretical contribution to the categorization of teachers' competencies.
\end{abstract}

\section{KEYWORDS}

Educational research, Alternative teaching methods, Teaching aids, Media literacy

\section{InTRODUCTION AND PRINCIPLES OF DEVELOPMENT}

Digital media are part of the everyday reality of adults and children. Digital media devices and offerings are diverse, with the smartphone playing a major role. In addition, children and adolescents often have numerous other digital devices (Education Group, 2015, p. 4). The availability of digital media is also changing the parameters for school education. According to Döbeli Honegger (2016, p. 654), "the school is therefore faced with the challenge of preparing differently socialized children and young people with additional, new tools for a changing and yet unknown world of work and life. This development has a massive impact on the educational mission in general and school instruction in particular. As several studies (e. g. OECD 2015) have shown in the meantime, using digital tools in the classroom arbitrarily or for no proper pedagogic reason does not automatically lead to an improvement of the teaching/learning situation, but possibly even to the contrary. Where digital media are used in deliberate combination and by digitally competent teachers, however, effects can be astonishing and extremely beneficial to learning (Fullan 2016, p. 6). Therefore, it is also important in Austria that digitally competent teachers support the pupils in learning in the best possible way. 
Initiatives have been launched in recent years to define more precisely which competencies would be necessary in this context; for example, Bachinger et al. (2013) have defined and exemplified competences for students of teacher training programmes in dealing with digital media and technologies. However, there is no developed competence model for teachers who are already working in practice, e. g. as the one based on the digi.komp series of competence models for Austrian pupils. Such a model would be essential, however, in order to point the way to digitally competent teaching and learning in a transparent and structured manner for both prospective and experienced teachers.

For the competence model digi.komp 8, the Federal Institute for Educational Research, Innovation and Development of the Austrian school system carried out accompanying research (Petrovic \& Svecnik, 2014). The results show that digi.komp 8 is perceived very positively by the e-learning contact persons and the head teachers, but simultaneously the level of awareness was still low at that time (Petrovic \& Svecnik, 2014, p. 24). School principals are particularly positive about the competence model in that the critical and conscious handling of digital media has been given adequate significance, that the offers in connection with digi.komp8 are helpful and that it is easier to meet curriculum requirements with the model (Petrovic \& Svecnik, 2014, p. 15). The main obstacles to the implementation of digi.komp 8 are seen in the multitude of education policy measures, insufficient resources on site and the lack of both the digital competence of the teachers and and the interest shown by them (Petrovic \& Svecnik, 2014, p. 21).

Against this background, the University College of Virtual Teacher Education was commissioned by the Federal Ministry of Education and Women's Issues to coordinate a development model of media literacy for teachers in the age of digitality. This model should take into account the Austrian education system in general and the different stages of the development of digital competences of teachers in particular. Since these aspects have not been sufficiently taken into account in existing international models, it was decided to develop a specific model for Austrian teacher training and teachers in practice: digi.kompP.

- Four principles were determined in advance for the development of the competency model:

- The compatibility of the competence catalogue with internationally used frameworks and formulated competence models must be ensured.

- The ability to connect to the existing digital competence models for pupils (Federal Ministry of Education and Women, 2013) in Austria should be guaranteed. This should also ensure compatibility with the existing self-assessment tool for teachers - the DIGIcheck.

- The structure of the model framework should be comprehensible at a glance.

- The categorisation should facilitate coherence with the domains of teacher training and should also be practicable in further education and training.

The following section 2 provides a brief overview of international models that were relevant for the development of the competence grid. After that the competence grid with its categories is presented in section 3. Section 4 concludes with a discussion of the integration of the competence grid into the international framework and its benefits in the Austrian education system.

\section{OVERVIEW OF INTERNATIONAL MODELS}

In order to ensure international connectivity, various frameworks and competence models on digital competences in Europe and beyond have been studied (e. g. Western Australia Department of Education and Training, 2004; Koehler \& Mishra, 2006; ISTE International Society for Technology in Education, 2007; United Nations Educational Scientific and Cultural 
Organization, 2011; Fraillon, Schulz \& Ainley, 2013; Kreuh, 2012). This research served as a valuable background for reflection and inspiration for the work on the digi.kompP model. The development of the DIGCOMP framework of the EU Commission (Ferrari, 2013) shows that the topic of digital competences for teachers can no longer be ignored. This framework model focuses on eight basic competences, which are to be acquired and further deepened in the sense of life-long learning; the model was used as a reference for the completeness and consistency of the digi.kompP model in the ongoing development process.

A detailed examination of all these models would go beyond the scope of this publication, so only the models selected for the development of the digi.kompP model will be briefly presented here.

\subsection{Technological Pedagogical Content Knowledge}

The framework model Technological Pedagogical Content Knowledge (TPCK, Koehler \& Mishra 2006) was developed to cope with the existing concepts at that time with regard to the competences of the teachers in dealing with electronic media, which, according to the authors, placed too much value on technical knowledge. Instead, the question of how technology is used should be given priority (Koehler \& Mishra, 2006, p. 1018). The development of theories on didactics is seen as a difficult undertaking due to the complex relationships. Therefore, Koehler and Mishra refer to the concept of pedagogical content knowledge by Shulman (1986) in this respect. Shulman distinguishes between areas that overlap and those that are limited by certain parameters:

„Teachers must not only be capable of defining for students the accepted truths in a domain. They must also be able to explain why a particular proposition is deemed warranted, why it is worth knowing, and how it relates to other propositions, both within the discipline and without, both in theory and in practice. " (Shulman, 1986, p. 9)

Koehler and Mishra now complement the domains pedagogical knowledge and content knowledge with technological knowledge (Koehler \& Mishra, 2006, p. 1026). This results in a model with three areas of competence and four overlapping surfaces, as shown in the following figure:

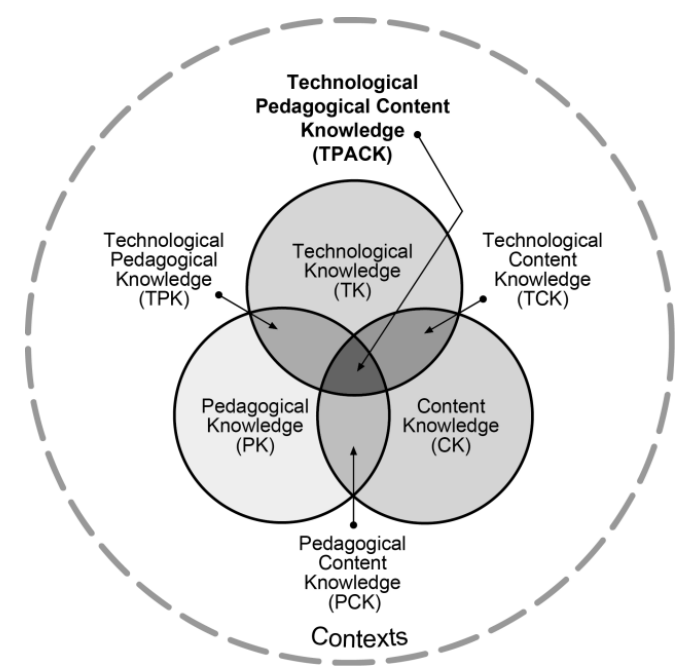

Figure 1: Model TPCK (Koehler and Mishra, 2006, p. 1025, Reproduced by permission of the publisher, (c) 2012 by tpack.org) 
The core of the model is the complex interplay between the three components content (CK), pedagogy (PK) and technology (TK); however, these three task areas are not considered in isolation (Koehler, 2012). On the contrary, it is emphasized that these components are always to be considered and analysed as part of the larger whole (Koehler \& Mishra, 2006, p. 1040).

Content knowledge stands for the domain of subject-specific knowledge, which teachers need for designing their lessons. Content knowledge thus includes the knowledge of the lecturers about the content of their subject matter; this includes concepts, theories, ideas, organisational parameters, proofs and evidence of the department (Koehler, 2012).

Pedagogical knowledge contains the didactic knowledge a teacher should have. This includes knowledge of the processes of teaching and learning, the overarching goals of pedagogy, values and goals, as well as lesson planning and management (Koehler \& Mishra, 2006, p. 1026). Pedagogical knowledge is of great importance in connection with the segment of digital competence of teachers.

Technological knowledge encompasses the general technical knowledge needed to use media in the classroom. In this context, chalk and blackboard are mentioned, and more advanced media such as the Internet and digital video are added (Koehler \& Mishra, 2006, p. 1027). Technological knowledge includes knowledge and skills in dealing with technology, tools and resources as well as the willingness to deal with the constant innovations and changes in this sector (Koehler, 2012).

As shown in Figure 1, these three areas are divided into four intersections.

Pedagogical content knowledge is the intersection that contains the transformation of knowledge into teaching. The preparation of the content, the conception of curricula, teaching, the evaluation of pupil performance and the interdependencies of these components are part of this segment.

Technological content knowledge stands for understanding how and in which form technology and content influence and limit each other. Teachers are expected to understand which technique is most appropriate for which content of their domain and how the content is changed by using a particular technique (Koehler, 2012).

Technological pedagogical knowledge synonymously refers to the knowledge of the interdependencies between technology and pedagogy. The question arises as to how the use of technology changes the teaching and which technique is suitable for which type of teaching.

The fourth intersection of all the three components is technological pedagogical content knowledge, which unites all the described areas: "TPCK is the basis of good teaching with technology and requires an understanding of the representation of concepts using technologies; pedagogical techniques that use technologies in constructive ways to teach content; knowledge of what makes concepts difficult or easy to learn and how technology can help redress some of the problems that students face; knowledge of students' prior knowledge and theories of epistemology; and knowledge of how technologies can be used to build on existing knowledge and to develop new epistemologies or strengthen old ones" (Koehler \& Mishra, 2006, p. 1029).

Mishra and Koehler do not see their model as a completely new concept. Their aim is to explain the idea that knowledge about technology cannot be presented in a decontextualized way with regard to content and pedagogy. They are aware that the separation of the three areas of content, pedagogy and technology is an analytical act, but it is not feasible in practice in this form 
(Koehler \& Mishra, 2006, p. 1029). It is also emphasised that the teacher's personality, the competence level of the learners, school-specific factors as well as demographic and cultural factors influence the interaction of the TPCK areas; therefore, each teaching situation is unique (Koehler, 2012).

\subsection{ICT Competence Framework for Teachers}

The ICT Competency Framework for Teachers of the UNESCO (United Nations Educational Scientific and Cultural Organization, 2011a) contains a very comprehensive list of the necessary competences for teachers. According to UNESCO, social and economic goals are central tasks of a country's education system; in order to achieve these goals, teachers must possess certain competencies, including skills in dealing with ICT (United Nations Educational Scientific and Cultural Organization, 2011a, p. 7). The aim of this competency model is to promote teachers' ICT competences while improving their skills in the field of education and school organisation in general (Open Education Europe, 2011).

Economists have identified three factors that lead to economic growth: the increase in capital intensity, higher quality work and technological innovation. These three factors are mapped in a complementary manner onto the teaching staff. It is emphasised that it is not enough for teachers to possess competences in the use of ICT and to be able to use ICT in the classroom. They must also be able to actively support students in creative work, collaboration and problem-solving learning with ICT (United Nations Educational Scientific and Cultural Organization, 2011b). The framework model therefore distinguishes between the six categories scientific and cultural organization, understanding ICT in education, curriculum and assessment, pedagogy, ICT organisation and administration, teacher professional learning (United Nations Educational Scientific and Cultural Organization, 2011a, p. 10). The combination of the three approaches with the six defined areas of competence results in the following grid, which contains eighteen elements:

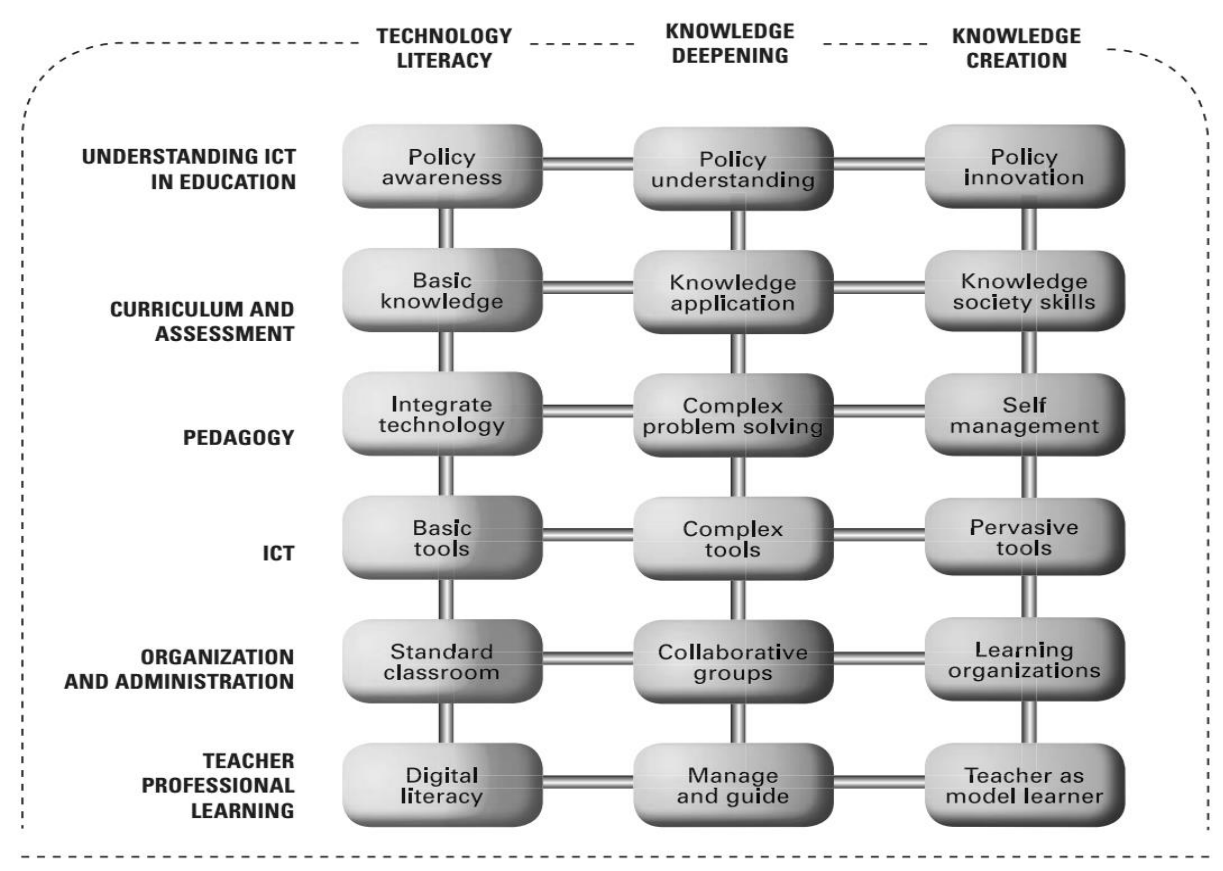

Figure 2: The UNESCO Competence Model for Teachers (Source: United Nations Educational Scientific and Cultural Organization 2011a) 
The three defined sections technology literacy, knowledge deepening and knowledge creation represent successive stages in the competence development of teachers (United Nations Educational Scientific and Cultural Organization, 2011b).

The aim of the section technology literacy is to enable teachers to promote social development and increase economic productivity through the use of ICT (United Nations Educational Scientific and Cultural Organization, 2011a, p. 9).

In this concept, knowledge deepening was described as the task of applying and deepening the acquired knowledge in practical working and living situations (United Nations Educational Scientific and Cultural Organization, 2011a, p. 11).

For the section knowledge creation, it was defined as goal that all people are actively involved in building up their own knowledge in the sense of life-long learning and that they should benefit from it (United Nations Educational Scientific and Cultural Organization, 2011a, p. 13).

Although this competency model was developed primarily for teachers at primary and secondary level, the authors stress that the model is also valid for all other areas of education, i. e. for students in teaching professions, headmasters and ICT officers at schools (United Nations Educational Scientific and Cultural Organization, 2011a, p. 8).

\subsection{The Model Digital Bildung}

The definition of the development stages of the digi.kompP model was based on a large-scale study conducted in Norway in 2012/13 on the acquisition of digital skills of teachers, based on the Digital Education model (Krumsvik, 2014). According to Krumsvik (2012, p. 466), digital literacy of teachers means "the individual teacher proficiency in using ICT in school with good pedagogical judgement and his/her awareness of its implications for learning strategies and the digital Bildung (sic!) of students." The German term Bildung was deliberately chosen because the term includes an integrative, holistic approach that allows the reflection on the effects of ICT on different aspects of human development (Søby, 2003, p. 8).

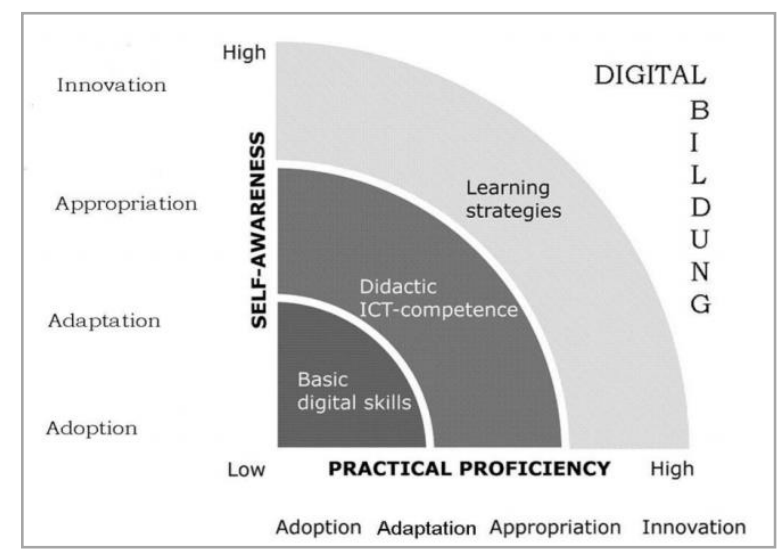

Figure 3: Digital competences of teachers according to Krumsvik (Source: Krumsvik, 2013)

The digital competences of educators are understood as the space of action between the two axes self awareness and practical proficiency; figure 3 illustrates this relationship. The model thus takes into account the mental and practical learning process (Krumvik 2013, p. 174). It is 
essential that both axes, which each lead to adoption, adaptation, appropriation and innovation, are equally considered in the acquisition of competence.

As in the UNESCO model, the competency model assumes that competence is built up in three basic stages: from basic digital skills to Didactic ICT competence and finally to learning strategies. The latter two stages are specific to teachers.

Didactic ICT-competence includes two things: the aspect that teachers act as role models for their students with regard to the pedagogical and didactic use of digital media in the classroom as well as the competence to reflect and evaluate digital media offerings in terms of meaningful didactic use (Krumsvik 2013, p. 176). Learning strategies is the term used to describe both the knowledge of one's own learning strategies for acquiring digital/educational competences and the ability of students to serve as a 'guide' in building up their competences (Krumsvik 2013, p. 176).

\section{The Digi.Kompp Competence Model In Detail}

$$
\text { digi.kompP - DIGITAL COMPETENCIES FOR TEACHERS }
$$

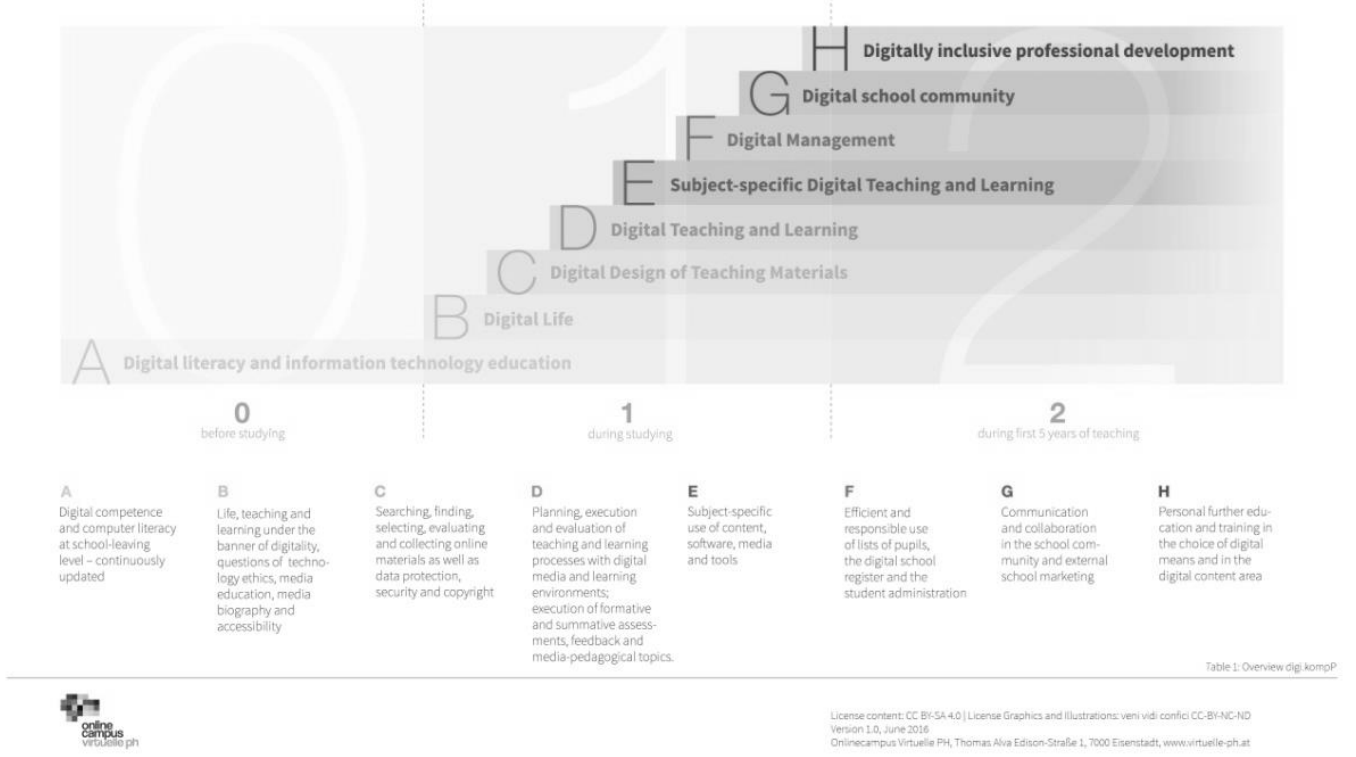

Figure 4: The competence model digi.kompP (CC BY, Brandhofer et al., 2016)

The digi.kompP competence model comprises eight categories $(\mathrm{A}-\mathrm{H})$; the acquisition of competence itself covers three development stages $(0-2)$. The competences at level 0 correspond to those of the competency model digi.komp12 (Federal Ministry of Education and Women, 2013), which students (should) have at the beginning of their studies. The start of the course corresponds with the transition from level 0 to level 1 , and stage 1 comprises the competences to be acquired during the teaching degree course. The transition from level 1 to level 2 is therefore made when the teacher training course is completed and the practical teaching starts. Stage 2 describes the competences acquired in the course of daily work, continuous professional development and further training. 
In the following subchapters, the respective categories and the acquisition of competence on these levels are briefly and concisely presented. For the formulation of the detailed catalogue of competences, the White Paper of the e-learning strategy group of Austria's pedagogical universities was largely used as a basis (Bachinger et al., 2013).

\subsection{Category A - Digital Literacy and Information Technology Education}

Category A corresponds to the level digi.komp12, which describes the acquisition of digital competences after completing 12th grade (school-leaving certificate) and includes competences in the fields of informatics in society, informatics systems and applied and practical informatics (Federal Ministry of Education and Women, 2013). Stage 0 in the competence model digi.kompP therefore refers to digital competence and computer literacy at school-leaving level; in stages 1 and 2 , these contents are continuously updated.

\subsection{Category B - Digital Life}

Life, teaching and learning under the banner of digitality, questions of technology ethics, media education and media biography as well as accessibility are contents of category B.

In stage 1, i. e. during teacher training, this means, for example, that students and prospective teachers should be able to describe the interactions between technology and society and thus identify opportunities for sustainable education. It is also necessary to become aware of the general effects of digital media on the educational landscape - i. e. the change of leading media (more precisely: transformation of leading media) - the changing role model of teachers and the impact of the media on pupils. However, it is not only about the impact of media on learners, but also about the competence to reflect on one's own actions and the possibilities digital media offer for knowledge management. Consumer protection and accessibility complete this category.

While in stagel the focus is on recognising, assessing and testing, in stage 2 the focus is on the (goal-oriented) use of competences and their practical implementation.

\subsection{Category C - Digital Design of Teaching Materials}

In stage 1, the focus is on searching, finding, selecting, evaluating and collecting online materials. The evaluation of applications and web-based resources leads to the planning of the didactic use, i. e. the preparation of topics and the creation or adaptation of materials to support learning processes. Legal issues must not be disregarded: data protection and security as well as copyright are key issues here. Furthermore, the ability to provide materials as Open Educational Resources is to be acquired.

In stage 2, the competences are extended to include the ability to maintain and adapt the pool of materials permanently as well as the knowledge of current changes in copyright law.

\subsection{Category D - Digital Teaching and Learning}

The category digital teaching and learning covers the planning, execution and evaluation of teaching and learning processes with digital media and learning environments as well as the execution of formative and summative assessments, feedback and media-pedagogical topics.

In stage 1, competences are acquired that allow teachers to support students in the best possible way by planning and designing lessons and learning processes using digital media. This also includes the design and use of learning management systems and the evaluation of media- 
supported project work. At this stage, students should always be aware of media-pedagogical topics.

In stage 2, the focus is on the use of digital media in accordance with modern learning theories along the entire range of technical and didactic offerings available: learning platforms, eportfolios, apps, e-assessment. Peer learning and tutorials are also to be used adequately and it is expected that learners in all areas of media education will be accompanied and coached.

\subsection{Category E - Subject-specific Digital Teaching and Learning}

This category deals with the subject-specific use of content, software, media and tools in a way that is conducive to learning. In stage 1, this means reflecting on the potential applications of information and communication technology for school purposes with a specific focus on the different subjects and the realization of specialist courses with digital media. It is a matter of being able to design learning settings and implement digital content, as well as getting to know and learning to use subject-specific apps and how to implement them in the classroom in a way that encourages learning and that is goal-oriented.

Stage 2 focuses on the adaptation of content, the evaluation and implementation of new apps and software, as well as the supervision of students writing their pre-scientific papers, as long as this involves the use of IT by the learners.

\subsection{Category F - Digital Management}

This category describes the efficient and responsible use of lists of pupils, the digital school register and the student administration.

Stage 1 competencies include, for example, adapting class lists and using cloud services to manage documents and IT systems to support both personal organizational processes and teaching. Furthermore, you learn how to manage the user administration of a learning platform.

Stage 2 will focus on the application of web solutions for school organisation, the management of digital class books and the effective use of administrative systems for pupils.

\subsection{Category G - Digital School Community}

This category deals with communication and collaboration in the school community and with external school marketing. Stage 1 provides for the acquisition of competences necessary for the use of applications, digital media and terminal equipment for communication and cooperation with all stakeholders, as well as for the design of public relations work at school - taking into account netiquette rules, of course. In Stage 2, these competencies will be expanded to include the use of digital media for location marketing and the ability to develop knowledge and project management skills in the school community.

\subsection{Category H - Digitally Inclusive Professional Development}

Category $\mathrm{H}$ relates to personal further education and training: both in the choice of digital means, i. e. in the mode, and in the digital content area. In stage 1, competences belonging to this category are assigned to the individual's own scientific training: research and evaluation of information as well as the writing of scientific papers using digital media including software for the analysis of data and texts for research purposes. In stage 2, the competences expand and focus 
on the teaching profession in general and one's own role as a member of the pedagogical profession. This means that one's own behaviour in social media must be designed in a way that is appropriate to one's role and consciously designed; software can be used for personal management; information and materials can be found and shared in digital collaboration rooms and can be acted upon in online communities. It is all about the competence to use digital tools (IKM, BIST, various diagnostic tools) to identify the learning status and progress of pupils and, in general, to include virtual space and digital media as self-evident components and aspects in their own professional activities and to be able to combine them in a masterful and innovative way.

In the following section 3.9, we will briefly discuss how the digi.kompP competence grid relates to the models described above, which form the basis for it. The final section 3.10 gives an outlook for the implementation of this model in teacher training programmes as well as in further education programmes for teachers in Austria.

\subsection{Classification in the Selected Theoretical Framework}

In accordance with Krumsvik's work (2014), three stages were defined for the competency model.

- digi.kompP stage $0=$ Basic digital skills

- digi.kompP stage 1 = Didactic ICT-competence

- digi.kompP stage 2 = Learning strategies

By combining the horizontal dimension of practical proficiency (Krumsvik, 2014) and its threestage development with the model TPCK (Mishra and Koehler 2006), consisting of three concentric circles, one can imagine both models together as three gradually growing concentric circles in the areas of content knowledge (CK), pedagogical knowledge (PK) and technological knowledge (TK).

The vertical dimension of self-awareness, i. e. reflexivity, would then be a third axis at a right angle to this, which always refers to all the three competence areas of the TPCK model. The following figure 5 shows this model combination.

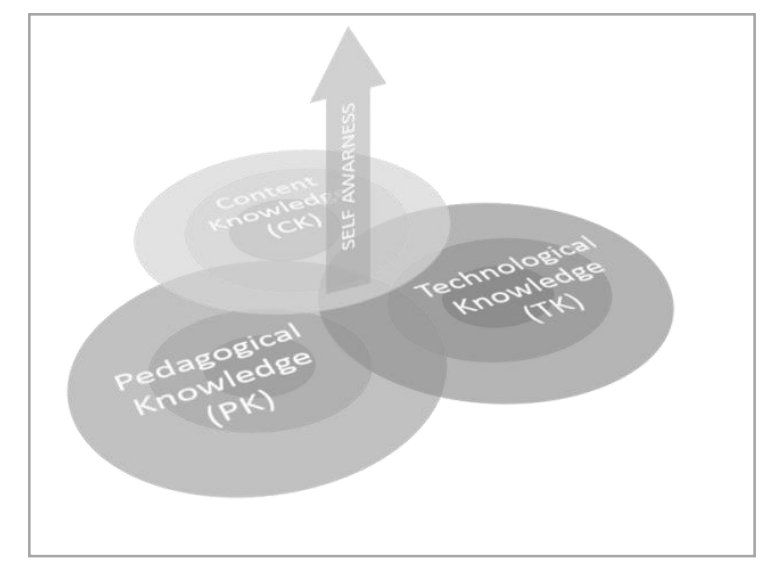

Figure 5: Combination of the competence models TPCK according to Mishra and Koehler and the model according to Krumsvik (Own illustration) 
The eight categories of the digi.kompP model presented above can also be covered by the model TPCK (Mishra and Koehler, 2006) in the same way; this means that it is possible to check whether the specifications of the TPCK framework model have been correctly and completely taken into account in the digi.kompP model. In other words, what is the relationship between the three overlapping circles of the TPCK model and the eight categories of digi.kompP?

As figure 6 shows, category D (digital teaching and learning) lies in the field of pedagogical knowledge - the pedagogical core competence component par excellence. Technological knowledge is in category $\mathrm{F}$ (digital management), if it is about technical skills beyond teaching and learning. Category A (digital competences and information technology education, i. e. the subject matter) is located in content knowledge.

The remaining five categories are located in the intersections of the three circles: at the interface between pedagogical knowledge and technological knowledge is category $\mathrm{C}$ (designing digital materials), while category $\mathrm{G}$ (digital school community) is located in the overlapping area of technological knowledge and content knowledge. Category D (digital teaching and learning in the subject) can be found in the intersection of content knowledge and pedagogical knowledge. The two categories B (digital life) and $\mathrm{H}$ (digitally inclusive professional development) would be located in the common core zone of all three areas, technological pedagogical content knowledge.

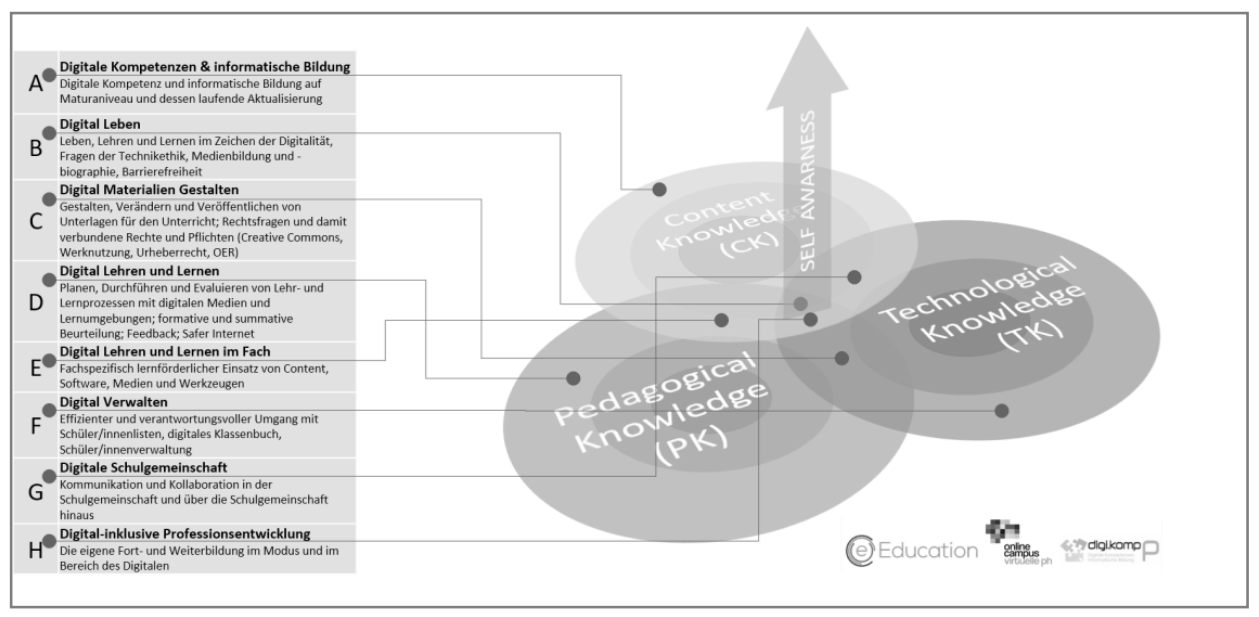

Figure 6: Mapping of digi.kompP onto the competence models TPCK according to Mishra \& Koehler and Krumsvik (Own illustration)

However, this assignment should not be overused. In particular, it is intended to clarify the completeness of the eight categories of the digi.kompP model and, conversely, to argue why the TPCK model (and no other) and the digital education model according to Krumsvik can rightly be regarded as an essential basis for digi.kompP. The UNESCO model (United Nations Educational Scientific and Cultural Organization, 2011a) served as a supplementary source for the formulation of the descriptors.

\subsection{Digi.Kompp in the Practice of Pedagogical Education}

The categorisation of the competence model presented has been chosen as a curriculum for the training of educators. It should be emphasised that the introduction to digital media literacy in education should correspond to education-oriented pedagogical training (Braunsteiner, Schnider \& Zahalka, 2014, p. 23). The particular implementation of the model is not a small claim in the training of teachers, and much remains to be done in order to achieve its fulfilment - also in the 
new training programme for educators (Klaus Himpsl-Guterman et al., 2016). The embedding of the eight digi.kompP categories into the curriculum subjects provides a basic orientation.

The curricula for this new teacher training programme have to identify three fields of study regardless of the respective modular architecture: 1) general basics of education sciences; 2) subject science and subject didactics; and 3) pedagogical-practical studies, whereby the subject science and subject didactics are to be regarded as two pillars of this third subject area of study (Braunsteiner et al., 2014, p. 64). In accordance with these guidelines, the digi.kompP model is assigned to the subject areas of study as follows: Category A digital literacy and information technology education corresponds to the prior knowledge that first-year students have gained in their school years, and any deficits should be compensated for before or at the beginning of their studies.

Category B digital life should be taken into account in the general basics of educational science due to the broad spectrum of this category.

The categories $\mathrm{C}$ digital materials and $\mathrm{D}$ digital teaching and learning are suitable for a separate course in the general and educational basics as well, while the category E digital teaching and learning in the subject is suitable for a treatment and deepening in the subject didactics.

In the practical school studies, the categories $\mathrm{F}$ digital administration and communication with digital media in the school community - category G digital school community - should be treated adequately.

Category $\mathrm{H}$ - digitally inclusive professional development - includes work with scientific texts, which could already find a place in the 'STEOP' (introductory and orientation period at university), as well as the development and reflection of a professional consciousness as educator in the course of the teacher training programme; later it becomes part of continuing education and training.

In terms of the development stages, this means, based on the Austrian teacher training as well as further education programmes, that the initial training should cover possible deficits from stage 0 and offer the competences from stage 1 . In the continuing education and training of teachers, any gaps from stage 1 should be closed and guidance to the competences of level 2 should be provided.

In a next step the development of a self-assessment test at the interfaces between stages 0 and 1 as well as 1 and 2 in accordance with the already existing DIGIcheck for teachers is envisaged (Brandhofer, 2014).

\section{DiscuSSION AND OUTLOOK}

In order to guarantee the acquisition of competence in the form described here, further education and training should be mentioned in addition to the consideration of this topic in the curricula of teacher training programmes at universities and colleges of education,. Here other forms could prove to be effective for acquiring and practicing new teaching strategies besides the familiar setting with half-day seminars: microteaching, video and audio feedback and practical exercises (Hattie, 2014, p. 120). Above all, in order to strengthen pedagogical knowledge, advanced training courses designed in the form of on-the-job training should be thought about, such as buddy systems. But also extensive further education in the form of training courses are justified, since a paradigm shift can be initiated through these (Brandhofer, 2015, p. 230). In order to strengthen the effect, it is advisable to refrain from pure application training and to take the Will 
Skill Tool Model (Knezek, Christensen \& Fluke, 2003) into account in the planning. This means that the frequent overemphasis on equipment issues (tool) should not be replaced by an overemphasis on the teacher's competences (skill), but that the teacher's convictions (will) should or must be taken into account (Knezek, Christensen \& Fluke, 2003; Brandhofer, 2015, p. 230). Training aimed at the teacher's pedagogical skills and expectations of self-efficacy should therefore be given priority.

The BMBF's eEducation Austria initiative, which focuses on the "didactically meaningful use of digital media in all subjects and the enhancement of pupils' informational skills" (BMBF 2016), shows that the development of the digi.kompP competence grid is on the pulse of the time, so that there is an added value for teaching and learning and that pupils acquire the competence to use digital technologies appropriately in their working lives. However, this goal will only be attainable with digitally competent teachers.

With the creation of the competence model digi.kompP, an attempt was made to complete the competence model series digi.komp4, digi.komp8 and digi.komp12/13 - from primary level to school-leaving level - with a model for teachers.

Based on several international models (especially Koehler \& Mishra, 2006, United Nations Educational Scientific and Cultural Organization, 2011a and Krumsvik, 2013), competences were developed in eight categories across three stages of development. The categories evolve from general digital competences to subject-specific and school administration competences in the digital sector, which are essential in today's teaching profession.

\section{REFERENCES}

[1] Bachinger, A., Brandhofer, G., Gabriel, S., Nosko, C., Schedler, M., Wegscheider, W. et al. (2013). Weißbuch zum Kompetenzaufbau von Pädagoginnen und Pädagogen für den Umgang mit digitalen Medien und Technologien. In P. Micheuz, A. Reiter, G. Brandhofer, M. Ebner \& B. Sabitzer (Hrsg.), Digitale Schule Österreich. Eine analoge Standortbestimmung anlässlich der eEducation Sommertagung 2013 (Band 297, p. 67-70). Vienna: Österreichische Computer Gesellschaft.

[2] Brandhofer, G., Kohl, A., Miglbauer, M., Narosy, T., Buchner, J., Groißböck, P. et al. (2016). Das digi.kompP Kompetenzmodell. Retrieved on November 28, 2020. Retrieved from: http://www.virtuelle-ph.at/wp-content/uploads/2016/01/digi.kompP-Langversion_Final.pdf

[3] Brandhofer, G. (2014). Kompetenzmodelle und Selbsteinschätzung als Grundlagen der Fortbildungsplanung - der DIGIcheck. Professionalisierung der Lehrenden der Fort- und Weiterbildung, Vienna.

[4] Brandhofer, G. (2015). Die Kompetenzen der Lehrenden an Schulen im Umgang mit digitalen Medien und die Wechselwirkungen zwischen Lehrtheorien und mediendidaktischem Handeln (Dissertation). Dresden: Technische Universität Dresden. Retrieved from http://nbnresolving.de/urn:nbn:de:bsz:14-qucosa-190208

[5] Braunsteiner, M.-L., Schnider, A. \& Zahalka, U. (2014). Grundlagen und Materialien zur Erstellung von Curricula. Graz: Leykam.

[6] Bundesministerium für Bildung und Frauen (2013). digi.komp12 - Das Kompetenzmodell Informatik 5. Klasse. digi.komp. Retrieved on November 28, 2020. Retrieved from http://digikomp.at/praxis/portale/digitale-

kompetenzen/digikomp12ahs/kompetenzmodelle/informatik-5-klasse.html

[7] Bundesministerium für Bildung und Frauen (2016). eEducation Austria: Digitale und informatische Kompetenzen für alle Schülerinnen und Schüler. Retrieved on November 28, 2020. Retrieved from http://eeducation.at/

[8] Döbeli Honegger, B. (2016). Mehr als 0 und 1. Schule in einer digitalisierten Welt. Bern: hep Verlag.

[9] Education Group (2015). Oberösterreichische Jugend-Medien-Studie 2015. Linz. 
[10] Ferrari, Anusca (2013). DIGCOMP: A Framework for Developing and Understanding Digital Competence in Europe. Sevilla: European Commission, Joint Research Centre, Institute for Prospective Technological Studies. Retrieved from http://ftp.jrc.es/EURdoc/JRC83167.pdf

[11] Fraillon, J., Schulz, W., Ainley, J., Australian Council for Educational Research \& International Association for the Evaluation of Educational Achievement. (2013). International Computer and Information Literacy Study: Assessment Framework. International Association for the Evaluation of Educational Achievement. Amsterdam.

[12] Fullan, M.; Quinn, J (2016). Coherence. The Right Drivers in Action for Schools, Districts, and Systems. Thousand Oaks: Corwin.

[13] Himpsl-Guterman, K., Berger, E., Brandhofer, Harrich, P., Maurek, J., Nárosy, T. et al. (2015). Wie "zukunftsreich" ist das neue Lehramtsstudium? Bestandsaufnahme zu Medienbildung und digitalen Kompetenzen in den Curriculaentwürfen der Sekundarstufe der PädagogInnenbildung_NEU. medienimpulse. $\quad$ Beiträge zur $\quad$ Medienpädagogik. http://www.medienimpulse.at/articles/view/868?navi=1, Retrieved on November 28, 2020

[14] ISTE International Society for Technology in Education (2007). ISTE Standards: Learning, teaching and leading in the digital age. Retrieved from http://www.iste.org/standards/iste-standards

[15] Knezek, G., Christensen, R. \& Fluke, R. (2003). Testing a Will, Skill, Tool Model of Technology Integration. Meeting of the American Educational Research Association, Chicago.

[16] Koehler, M. \& Mishra, P. (2006). Technological Pedagogical Content Knowledge: A Framework for Teacher Knowledge. Teachers College Record, 108 (8), 1017-1054.

[17] Koehler, M. (2012). TPACK Explained. TPACK Explained. Retrieved on November 28, 2020. Retrieved from http://tpack.org/

[18] Kreuh, N. (2012). Bulletin: The way towards e-competency. March 2012. Ljubljana: Republic of Slovenia, Ministry of Education, Science, Culture and Sport.

[19] Krumsvik, R. J. (2012). Teacher educators' digital competence. Scandinavian Journal of Educational Research 1 (12), DOI:10.1080/00313831.2012.72627

[20] Krumsvik, R.J.; Jones, L.Ö. (2013). Teachers' Digital Competence in Upper Secondary School: (Work In Progress). ICICTE 2013 Proceedings, 171-183 Retrieved from http://www.icicte.org/Proceedings2013/Papers\%202013/05-1-Krumsvik.pdf

[21] Krumsvik, R.J. (2014). Teacher educators' digital competence. Scandinavian Journal of Educational Research, 58 (3), 269-280. doi:10.1080/00313831.2012.726273

[22] OECD (2015). Students, Computers and Learning: Making the Connection. PISA, OECD Publishing.

[23] Petrovic, A. \& Svecnik, E. (2014). Digi.komp 8. Ergebnisse der Befragung der Schulleiter/innen sowie der E-Learning-Kontaktpersonen. Graz: Bundesinstitut für Bildungsforschung, Innovation \& Entwicklung des österreichischen Schulwesens.

[24] Shulman, L.S. (1986). Those Who Understand: Knowledge Growth in Teaching. Educational Researcher, 15 (2), 4-14.

[25] Slovensko Izobraževalno omrežje. (2012). Cilji standarda e-kompetentnosti. Retrieved on November 28, 2020. Retrieved from http://www.sio.si/sio/projekti/e_solstvo/cilji_standarda_e_kompetentnosti/

[26] Søby, M. (2003). Digital competence: from ICT skills to digital ,Bildung‘. ITU, University of Oslo.

[27] United Nations Educational Scientific and Cultural Organization. (2011). UNESCO ICT Competency Framework for Teachers. Retrieved on November 28, 2020. Retrieved from http://www.unesco.org/new/en/unesco/themes/icts/teacher-education/unesco-ict-competencyframework-for-teachers/

[28] United Nations Educational Scientific and Cultural Organization. (2011a). UNESCO ICT Competency Framework for Teachers. Paris: UNESCO.

[29] Western Australia Department of Education and Training. (2004). Competency framework for teachers. East Perth, W.A.: Dept. of Education and Training.

\section{AUTHORS}

Gerhard Brandhofer has a university professorship for media didactics and informatics education at the University College of Teacher Education in Lower Austria. The main areas of work include planning, teaching and research in the field of the use of digital media in primary and secondary education. Research activities and publications cover

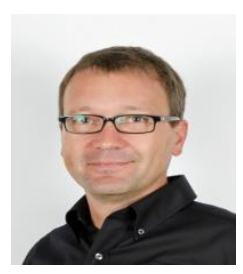


International Journal of Education (IJE) Vol.8, No.4, December 2020

the topics the use of digital media in schools and universities.

Marlene Miglbauer studied English/American Studies and History/Social Studies (teaching profession) at the Karl-Franzens-University Graz and Mary Immaculate College Limerick. Teaching activities at the University of Economics and the University of Applied Sciences Wiener Neustadt. In 2017, she completed the postgraduate master's degree in e-Education at the Danube University Krems with a thesis on language skills and digital competences in tertiary English teaching. Since autumn 2018 she has been head of the University College of Virtual Teacher Education.

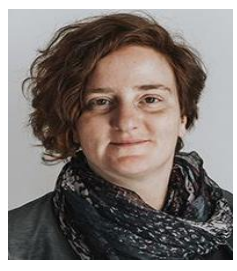

